\title{
Crossing Organizational Boundary's Effect on Paradigmatic Shift and the Implication to Marketing Strategy of an Organization
}

\author{
Riad Mustafa*, Fahrina Mustafa** \\ * Universitas Fajar, Jl. Prof. Abdurrahman Basalamah No. 101, Makassar-Indonesia \\ ** Postgraduate Student, Universitas Brawijaya, Malang-Indonesia
}

\begin{abstract}
This paper studies the paradigmatic shift as the effect on the crossing organizational boundaries activities. Boundary crossing as part of specific function of organizations is common to organization theories. Nevertheless, the increasing and strong rate of occurrence of the crossing boundary activities is considered important today as the consequence of the technological revolution in information and communication technology coupled with the future technologies. Crossing boundaries influence the people involved and the institutional sets. The relationships within the boundaries are increasingly dynamic. Hence, this, in turn, may lead to paradigmatic shift. From the perspective of organization and innovation studies these processes are to a great extent attractive since they may create different conditions the existing literatures on organization as well as innovation, and consequently, on marketing. Therefore, this paper aims at studying the marketing strategy response of an organization by identifying states that emerge or condition that may be created as the paradigms shifted.
\end{abstract}

Keywords: marketing strategy, innovation system, technological change, crossing boundary

\section{Introduction}

Our modern life is now at the brink of 'technological revolution' initiated by new set of technologies or 'attractor' that will change the way we live and work fundamentally (Schwab, 2016) and bring about an irruption or turbulence in the basic structure of economy, and of propelling long term upsurge of development (Perez, 2005). These set of technologies are sparked by the advance of information and communication technology and is fused by other emerging or new technological breakthroughs such as robotics, artificial intelligence, augmented reality, autonomous vehicles, biotechnology, nanotechnology, quantum computing, and others (Schwab, 2016). These technological breakthroughs or innovations has been changing and altering our daily economic activities which propagating to other social, political, cultural life.

Innovation is complex, dynamics and uncertain in nature called 'system of innovation' (Edquist, 1997). This new approach to economic aspects of innovation considers actors that consist of government, firm or industry, and universities or scientific organizations, and institutions or 'rule of the game' as the core of the work of innovation study. The complexities and uncertainties as one of the prominent characteristics of today's growth is the result of the interdependent and intertwined relationships among the main actors where prevailing institutions influence as well as are influenced by these relations. What is prominently identified these complex and intertwined 
characteristics of the relationship is the role of knowledge.

Knowledge became the critical components of today innovation that generates the development theoretical frameworks such as knowledge-based economy in economics and knowledgebased society in societal field to name a few. Firm has unique position to this as the only one actor that can drive information to valuable knowledge that leads to innovation (A. S. Metcalfe, 2013).

Learning is the important process to knowledge creating, development, utilization, and dissemination to firm (King, 2009) requiring firm to be learning organization (Senge, 1990) and even learning needs to done within organizational boundary crossing (Dickinson, 2013; Hult \& Jr., 2017). The importance of learning in organization can be described in five points, called 'fifth discipline', which are system thinking, personal mastery, mental model, building shared vision, and team learning (Senge, 1990).

From organization perspective, the crossing boundary needs to be adapted into structure of the firms, therefore later to firm's strategy including marketing. Different focuses relate to this marketing strategy of a firm are studied by scholars such as 'disruptive marketing strategy' (Hult \& Jr., 2017), holistic marketing (Kotler \& Keller, 2007), and salesmarketing encroachment effect (Keszey \& Biemans, 2016).

Summing up the above, the need of innovation in order to face the present dynamic and complex environment has forced the firm to rethink its strategy, including marketing. The paper aims at studying the firm's strategy as the response to this situation by identifying the states or conditions following this environment.

\section{Literature Review}

We have been facing technological advance generating revolution that we have never experienced before. It is now the phase of entering fourth industrial revolution (Schwab, 2016), or fifth revolution (Perez, 2005) where innovations emerge from strong and dynamic interlinked and intertwined relation between information and communication technology and many future technologies. The relation among these technologies is complex, posed high risks and uncertainties, systemic, and pathdependence (Dodgson, Gann, \& Salter, 2008). The change raises frenzy and transformational effect in social, economic and institutional and further generate discontinuities to the existing technology (Perez, 2005).

Knowledge plays the main role to this transformation (Fischer \& Fröhlich, 2001; Llrena \& Matt, 2005) affecting our society, known as knowledge-based society concept (Philips, 2013), as well as attracting scholars or theorists to examine theoretical framework of knowledge-based economy (Llrena \& Schenk, 2005). Hence, knowledge as 'justified personal belief' is generally distinguished as tacit and codified or explicit knowledge, as well as 'know what', 'know how' and 'know why' (King, 2009).

The complex and systemic condition mentioned above is one of the main characters from innovation system theoretical framework (Edquist, 1997; Fischer \& Fröhlich, 2001; Llrena \& Matt, 2005). In this respect, as a new approach to study innovation from economic perspective, Edquist argued that the complex nature of innovation system is the result of feedback mechanism and complex interactive relations that occur among different main actors (Edquist, 1997). These actors are involved in order to acquire, generate, and exchange knowledge and other significant resources (Fischer \& Fröhlich, 2001). Their relationships are influenced by prevailing institutional sets. However, agents also affect the institutions in most by dynamic ways (Dzisah \& Etzkowitz, 2013c). This institution is the 'rule of the game' and as an important component in the environment (Miles, 2012).

According to Miles referring to Scott, institution is defined as "regulative, normative, and cognitive structures and activities that provide stability and 
meaning for social behavior" (Miles, 2012) while from Carlsson and Stankiewicz cited by Edquist institution is defined as "both rules or laws determining behavior and organizational structures" (Edquist, 1997). According institutional theory, there are three levels of influence to institutionalized activities, namely individual, organizational and inter-organizational; hence, individual institutionalized activities are influenced by norms, habits, and traditions in individual layer; while systems of political, social, cultural, and beliefs influenced the organizational activities; and pressures to organizations come from government, alliance of industries, and society's expectation within inter-organizational influence (Miles, 2012). With regards to innovation, institutions are ubiquitous; they influence the relation between $R \& D$, production and marketing, they exist in relations between firms and households, as well as in relation between government agencies and private firms (Edquist, 1997).

Another main feature of innovation system perspective is learning process to deliver innovation (Bach \& Matt, 2005; Edquist, 1997; Llrena \& Schenk, 2005). Both knowledge as most fundamental resources, and learning as most significant process to organization, is what the modern business showed (Edquist, 1997). To organizations, learning becomes a crucial process in order to compete to the present complex business. Senge proposing 'learning organization' concept wrote, within more interconnected world and more complex and dynamic business condition, that work must be more "learningful" (Senge, 1990). The importance of learning in organization can be described in five points, called 'fifth discipline', which are system thinking, personal mastery, mental model, building shared vision, and team learning (Senge, 1990). Studying learning within organization context by knowledge management concept, King viewed that organizational learning is the goal of knowledge management by encouraging creation, dissemination and embedding knowledge into organizational process in order to improve its practices and pursuing the achievement of organization's goals continuously (King, 2009).

The way knowledge produced and transferred within organization is an interrelated process that takes place in a loosely, more temporal, and flexible coupled of networks that is built by autonomous actors who have heterogeneous interests (Dickinson, 2013). Studying the relation between science and society and the consequence for both, Dickinson argued that our contemporary society gave birth to socio-technical systems as we are generating, transferring and using knowledge research; the process that takes place by crossing boundaries of organizations (Dickinson, 2013).

According to Dickinson, boundary crossing deals with process (boundary work) within the context of spatialtemporal boundary and socio-political boundary. The process of crossing boundaries, or boundary work, may explain the innovatory work and technical change that may result in destructive, constructive and transformative way (Dickinson, 2013). The knowledge transfer and translation (boundary work) within boundaries is associated with boundary spanning role and institution which is facilitated for example by knowledge brokers who play the roles as building and forging relationship and networks that further affecting the collaborators' interests and identities (Dickinson, 2013).

Discussing organizational boundary crossing, it is useful to explain briefly concept of boundary spanning. According to Williams, boundary spanning is a function of "managing the interface between organizations and their environments", and citing Katz and Kahn, as a function of "export of services, ideas and products of material and people into the system" (Williams, 2010). From this definition, the roles of boundary spanning are among others as organizational representative, organizational liaison, foreign affair person, and internal communication start (Williams, 2010)

The rationales of crossing boundaries of organization can also be explained from the 'techno-economic paradigm' (Perez, 2005). 
Perez's concept investigates technological revolution and its consequences to economic, social, political and organizational aspect. According to her, there are two periods where each has different nature within the 'great surge of development' (Perez, 2005). Each period consists of two phases; eruption and frenzy phase for installation period phase of synergy and maturity for deployment period (Perez, 2005).

Boundary crossing in term of a continuing reconfiguration of organizational formats within different institutional sphere in which knowledge is put at the core of economic activities suggests the permeating activities across three main organizations; government, industries and scientific organizations (Dzisah \& Etzkowitz, 2013b). This 'triple helix' concept of government, industry, and scientific organization dealing with both these institutional sphere transformation of the organizations and their interrelations growingly shape the dynamics of innovation (Etzkowitz, 2013). Among these three actors of government, industries or firms, and scientific organizations, in term of translating knowledge into innovation, it is the innovating firm who can combine the knowledge into a plan for innovation (J. S. Metcalfe, 2013).

This unique 'final combinatorial responsibility' of an innovating firm in driving valuable information into innovation (J. S. Metcalfe, 2013) clearly shows the significance of knowledge resources and learning process to the firm. In order to assume this responsibility as innovative organizations, then firms must face the radical marketplace that is radically different from previous conditions in which new behavior, new opportunities and new challenges has been emerging (Kotler \& Keller, 2007), must have clear marketing focus as well as more advanced understanding of customer needs as the successful innovation requirements (Keszey \& Biemans, 2016), create superior customer value (Cepeda-Carrion, MarteloLandroguez, Leal-Rodríguez, \& LealMillán, 2016), be aware of firms' relation to their customers (Kotler \& Amstrong, 2012), and go further by proposing new framework of 'disruptive marketing strategy’ (Hult \& Jr., 2017).

At the level of organization, the needs for more complete and cohesive approach beyond the traditional approach to marketing concept, a 'holistic marketing' approach is developed (Kotler \& Keller, 2007). This approach aims at maximizing (1) value exploration by understanding the relationship among customers' cognitive space, firms' competence space, and collaborators' resources space, (2) value creation by identifying customers' new benefits, utilizing firms' core business, and choose and manage firm's business partners coming from their collaborator networks, and (3) value delivery by mastering customer relationship management, internal resources management and partnership relationship management (Kotler \& Keller, 2007).

\section{Methodology}

It is a theoretical and literature work and multidisciplinary study. In order to study the problem, literatures in the area of knowledge management, innovation system, technological change, boundary crossing, and marketing management are reviewed. These areas are selected based on the reason that they have common interest to technological change relating to the marketing concept and perspective in an organization. Marketing concepts is examined from these literatures; putting it into the context of technological change, are viewed from the perspective of boundary spanning, crossing, work and objects. The aim of this method is explore the bigger, or systemic, picture of the marketing concepts within the context of the present contemporary technological change. This exploration is oriented to identify conditions where the marketing concepts theoretically sufficient to work.

\section{Discussion, Result, and Suggestions}

Comparing to all technological revolution studies, the last or the fourth revolution as marked by Klaus Schwab (Schwab, 2016) or the fifth one as studied by Perez (Perez, 2005), shows distinct 
differences in term of the speed of the breakthrough it produces, its exponential evolvement, scope of disruption covering almost all industries, and of the change that deeply and widely affects systems in production, management and governance (Schwab, 2016). These three characteristics of speed or velocity, scope, and system impact showed that the coming contemporary technological revolution needs to be seen in multidisciplinary views in order to understand the emerging new challenges, and to the needs of different actors to, for instance, collaborate with (Dzisah \& Etzkowitz, 2013c; Etzkowitz, 2013). Organizations, namely government, university or research institution, and firm especially, are forced to be innovative (Edquist, 1997) to face this complex and uncertain environment. The technological revolution has pulled or tempted organization, society and institutions to interlink and intertwine each other, as one of the reasons, since advanced technologies increasingly reduced the temporal and spatial problems.

Perez depicted the atmosphere of technological revolution, described in her theory of 'techno-economic paradigm', as a situation in which technological changes have affected economic and financial sphere, later influenced institutional then social, cultural and even ideological sphere (Perez, 2005). Technological revolution produces its great changes to almost all aspects of life by the time when new technologies converge. Technological change issue has been affecting scholars from variety of fields to develop concepts. At least fields of economics, technology, social, and politics have contributed to the issue. We have identified from most of these fields some salient factors to the study of technological change. These are knowledge, innovation system, actors and the relationship among them, and institution (Bach \& Matt, 2005; Dzisah \& Etzkowitz, 2013b; Edquist, 1997; Fischer \& Fröhlich, 2001; Miles, 2012; Perez, 2005). It can be argued that all factors influence each other in a complex ways. The complexities express the conditions or characters of the beginning era of the coming technological revolution. These characteristics consist of systemic, complex, uncertainty, and intertwined relationship (Fischer \& Fröhlich, 2001; Llrena \& Matt, 2005). Considering these factors within the context of such common characteristics is helpful to examine where organizations, especially firms, may stand and what they can do.

System of innovation concept is one among other concepts that can be applied under such circumstances above. Christopher Freeman defined innovation system from national level as "the network of institutions in the public and private sectors whose activities and interactions initiate, import, modify and diffuse new technologies" (Edquist, 1997). Hence, Edquist highlighted common characteristics of system innovation, namely learning as the center of this framework, holistic and interdisciplinary, interdependence and non-linearity, and the central role of actors and institutions (Edquist, 1997) as system of innovation is developed from variety of fields of study. This concept departs from the idea that innovation does not work in isolation but are generated by different agents who interact each other and who whose ultimate goal is to produce and diffuse knowledge (Fischer \& Fröhlich, 2001) by complex patterns of interactions among these agents (Dzisah \& Etzkowitz, 2013a; Fischer \& Fröhlich, 2001) and influenced as well as are influenced by shared institutional settings (Dzisah \& Etzkowitz, 2013a; Miles, 2012). The actors that consist of government, industry, and academic or research institution, established, built, rebuilt their relations (Dzisah \& Etzkowitz, $2013 \mathrm{~b}$ ) in order to create innovation. At the same time, referring to the 'triple helix' concept, these actors' relationships are shaped by their shared-institutions (Etzkowitz, 2013). The opposite direction also works with the similar importance, in which shared-institutions are influenced by actors (Miles, 2012).

The relationship among these actors has been increasingly crossing their internal and external boundaries of organization (Dickinson, 2013). This organizational boundary crossing is temporal and complicated as it deals with managing different interests from variety of identities 
(Dickinson, 2013), therefore it carries uncertainties (Miles, 2012). Although this troublesome environment, firms are forced to cross their or other boundaries in order to be innovative. Firms must try hard since innovation system 'do not exist naturally' (J. S. Metcalfe, 2013). Rather, innovation should be constructed, instituted for facilitating the pursuit of firms' competitive advantages (J. S. Metcalfe, 2013). Etzkowitz's 'triple helix' concept concerning the general pattern of relationship among three actors showed that institutional transformation shapes the dynamics of innovation (Etzkowitz, 2013), the transformation is the outcome process of knowledge acquisition, translation, dissemination and exchange (Dickinson, 2013; Llrena \& Matt, 2005). This process of 'capitalization and commodification' of knowledge takes place by eliminating boundary between these organizations or actors (Dickinson, 2013). Knowledge as the main determinant to present success and innovativeness of a firm is discussed by many scholars under such concepts as of knowledge-based economy (Dzisah \& Etzkowitz, 2013c; Fischer \& Fröhlich, 2001; Llrena \& Matt, 2005), knowledge-based society (Dickinson, 2013), knowledge-intensive community (Cohendet \& Mehyer-Krahmer, 2005), and knowledge-based of a firm (Miles, 2012).

Within this context of contemporary technological change involving important factors and identified characteristics as mentioned above, marketing activities as one of the main functions of organization have been evolving through sustained adaptation (Cepeda-Carrion et al., 2016) in facing its increasingly dynamic environment as marketing permeated all aspects of organization and even connect to multiple companies (Hult \& Jr., 2017). In this regard, Hult \& Jr. proposed the concept of 'disruptive marketing strategy' that is developed from their theory of boundary-spanning marketing and organization studied the way to implement the marketing concepts by looking at crossdepartmental and cross-organizational marketing activities and function in order to understand market-based value creation of a firm (Hult \& Jr., 2017). Their theory is drawn out between theory of marketing and organization what they called as 'marketing organization theory' (Hult \& Jr., 2017). Hence, marketing concept is translated as activities that initially come from applications within organization's department or functions that later relentlessly move across organization department or function, and after a period of time to external organization in order to deliver organization's market-based value (Hult \& Jr., 2017). At this point, 'marketing orientation' is a cross-departmental and cross-company activities or organizational boundary spanning involving crossing within activities, among networks, in process, and among stakeholders (Hult \& Jr., 2017). Although Hult \& Jr. mapped organizational boundary spanning, they did not explain further how this boundary spanning works. They did not further elaborate important atmosphere in which this boundary crossing takes place. Therefore, the dynamics of the crossing activities, for example, in boundary spanning among internal networks, vertical networks, intermarket networks, and opportunity networks.

Theory of 'boundary spanning marketing organization' of Hull \& Jr. is one among other theoretical frameworks identified from selected literatures of our work to show how firms should dynamically adapt to their robust forces of contemporary condition. Other concepts are including expanded model of the marketing process in order to create value for customers who later create value for firm (Kotler \& Amstrong, 2012), called 'holistic marketing' that integrates four main dimensions of marketing activities (Kotler \& Keller, 2007), sales-marketing encroachment concept (Keszey \& Biemans, 2016), and the relation between organizational process and firms' capabilities in the context of today datarich environment (Orlandi, 2016).

Kotler and Amstrong's 'holistic marketing' concept suggested the interaction among related actors within inter- or intra-organization with their respective value-based activities in order to create, sustain, and renew the values. The concept underlined the vastness of and 
interdependence of marketing activities (Kotler \& Keller, 2007) which are translated into four marketing dimensions; internal marketing, performance marketing, relationship marketing, and integrated marketing (Kotler \& Keller, 2007). Among these dimensions, 'relationship marketing' is the one that can be examined within boundary crossing context by means of collaborative works, networking, and others. This 'relationship marketing' dimension aims at generating marketing network as a unique asset of the firm to its end result through developing satisfaction-based long-term relationship with their key constituencies in order to obtain and to sustain their business. It also aims at more emphasizing on retaining customers. Firms should have been capable not in only Customer Relationship Management but also in Partner Relationship Management (PRM). Delivering values to end customers is also a role of firms' key distributors and suppliers. The basic operation of this dimension is about building networks that consist of firm's stakeholders, later these networks generate advantage or profit (Kotler \& Keller, 2007). Their key constituencies are customers, employers, marketing partners, and financial communities. In general, 'holistic marketing' concept explores how contemporary marketing functions within intra- and inter-organization. It can be suggested that the function is a boundary spanning. Exploring further with regard to how the process within this boundary spanning is missing from this concept. Therefore, how crossing boundary takes place and which object of the crossing process should be taken into account, be it person, method, or repository (Dickinson, 2013) is missing. Knowing the this process or 'boundary work' and 'boundary object' is way to understand the characteristics of this crossing that is useful as a source for strategy formulation in term of innovation building.

The rationales of crossing boundaries of organization where 'holistic marketing' approach is suggested to deal with can also be explored from the 'techno-economic paradigm' (Perez, 2005). Perez investigates technological revolution and its consequences to economic, social, political and organizational aspect. According to her, there are two periods where each has different nature within the 'great surge of development' (Perez, 2005). Each period consists of two phases; eruption and frenzy phase for installation period phase of synergy and maturity for deployment period (Perez, 2005). Techno-economic and 'great surge of development concept is a concept that can picture the conditions and to identify actors with their respective roles.

Putting the contemporary situation of business within Perez's concept of 'great surge of development' our work can go to suggest that we are now at the phase of irruption (Perez, 2005). This irruption phase, according to her, is characterized by "disrupting established fabric, pronouncing new industrial networks, setting up new infrastructures, spreading new ways of doing things" (Perez, 2005). At the beginning of these new technologies, it needs to establish the whole new networks that interconnect services. It follows later with cultural adaptation (Perez, 2005). To these principles underlying technologies, adaptation means also to learn and to understand organizational concept relates to the technological change paradigm. Perez marked at this point as the beginning of firm's transformation. To end, institution is then wider set up. This phase is characterized by (1) the old-paradigm firms still have the potential instrument money, (2) increasing unemployment, and (3) situation is depicted as despair, impotence, and bewildering, (4) and divergence between the old and the new, either in political, economic, social, or technological, takes place (Perez, 2005). Further notion can be offered to these characteristics that besides boundary spanning, in term of involving more actors, individuals or groups, to be involved, the boundary work or process either in socioeconomic boundaries context or in spatialtemporal boundaries (Dickinson, 2013) is critical to this irruption phase.

From discussion of technological change above, it is important to notice that scholars from various research interests who have been increasingly working on 
different issues relating to concept of marketing activity and function should work within multidisciplinary way in order to have clear picture of the environment or of system (Fischer \& Fröhlich, 2001; Senge, 1990). The reason is that the systemic consequences of the parallel internal and external environmental change of a firm are hard to capture by mono-discipline approach. The changes that potentially generate from incremental to radical innovation influenced the prevailing or existing institutional settings of external or internal relation of a firm. One of the results is disturbances to paradigm of a firm in which the strategy formulation and development is based. The paradigm or the basis for defining firm's strategy is forced to change in order to deal with uncertainty, to manage conflict and cooperation, and to provide incentives (Edquist, 1997). It is the condition where the paradigm is forced to change.

Another important point to discuss is the critical role of knowledge and the consequence on generating organizational learning process. Most theorists or scholars from innovation study show the important role of knowledge to create organization's innovativeness and therefore competitiveness (Cohendet \& MehyerKrahmer, 2005; Edquist, 1997; Fischer \& Fröhlich, 2001; Llrena \& Matt, 2005). The selected literatures relevant to marketing concept of a firm show their different attention to this knowledge. The 'disruptive marketing strategy' concept (Hult \& Jr., 2017), for example, does not describe directly knowledge factor to their framework. However, information as a source of knowledge (Miles, 2012) is one of their five main perspectives of their theory of 'boundary-spanning marketing organization' in term of 'decision making perspectives'. The concept of 'salesmarketing encroachment' (Keszey \& Biemans, 2016) that examines the sales intruding on marketing tasks domain in order to improve the new product development performance do not put knowledge as part of their theoretical discussion although their work deal with crossing departmental boundaries of sales and marketing.
Important factor that also increasingly gives the complexity and uncertainty to the system of technological change is the interlinkage and intertwinement among actors in one side and between actors and the institutional sets in another side. Interlinked and intertwined relation among government, private firm, and scientific organization such as university or research institution is partly because of the needs of these actors to innovate. Innovation can be done in isolation, the firm requires interactive relation and feedback mechanism in order to translate knowledge that the firm acquired (Edquist, 1997). Firm behavior is shaped by institutions such as laws, regulation, norms and technical standard (Edquist, 1997). Institution, according to Edquist, is one of the striking characteristics of innovation system conceptual framework (Edquist, 1997). There is period, of 'frenzy period' in Perez's concept, in that institutional change is called for, however, at the same time faces resistance to change as well.

Examining this dynamic characteristics relationship among actors in the 'marketing concept' framework would be very helpful to identify these characteristics. Collaborative works is one of the kind of relationships that is common strategy to firm (Dickinson, 2013). Collaborative work, as part of boundary crossing approach, apart from compelling, is both complex and problematic that may result in high rate of failure in private sector (Williams, 2010). Collaborative process involves knowledge and interests as social life dimension that are interrelated and are heterogeneous as identity come from a range of differences in nationality, gender, ethnicity, class and others (Dickinson, 2013). As a network, it contains high risks such due to friction, poor communication, continuing conflicts over resources, objectives and others (Tidd, Bessant, \& Pavitt, 2005). In this respect, interest is always as a source of differences and changes that in turn produce two different results. The process can results in conflict, resistance, and or submission, and in other end, it can be as an incubator for collaboration, cooperation, and innovation (Dickinson, 2013). Dickinson explained that this process, or boundary work, is "a 
unity of destructive, constructive, and transformative process" (Dickinson, 2013). Transformative process is important to innovation process where it consists of process knowledge transfer and translation involving efforts of identifying, redefining and harmonizing heterogeneous interests (Dickinson, 2013).

Summarizing up discussion above, some results are suggested as follows. Innovation cannot work in isolation. To be innovative, therefore be competitive, then government, firm or industry, and university or academic institution must work together. They cross each other boundaries for that purposes. To operationalize the relationship then institutional framework is set as the "rule of the game" of the relationship that shapes the actors' behaviors. However, actors also influence the institutions. In term of technological revolution period, the context of actors, context of their relationships, and context of institutional setting is different from each phase from Perez's concept. At the beginning of technological revolution phase, namely 'irruption', actors are mostly old-paradigm technologies, the relationship is loosely, temporal and dynamic. It is because institutional settings that support the new technologies is still missing. The social, political, and cultural context of this institution is still within the old-paradigm of technology. However, a divergence occurred between this new- and old-paradigm within economic, cultural, social, political, technological, and even ideological. Marketing concepts therefore show the reaction to this phenomenon as our study showed. All realize the need to build relationship, such as networking. Most of the concepts discuss about boundary spanning and crossing. Nevertheless they do not go further to describe how they do this relationship and how their boundary work should operate. The scholars did not define clearly which focuses on their boundary spanning should be taken into account. The reason for the lack of boundary-work and boundaryobject explanation is that the firms are in dynamic technological change period especially on the still domination of the old institutional settings. All concepts of contemporary marketing have been realizing this situation. It needs, however, wider and deeper multidisciplinary works under the context of spatial-temporal as well as socio-political. Consequence to marketing strategy is then critical. Most firms within the irruption phase of Perez are still highly tied or embedded to the present or old-paradigm of technology. One uneasy choice to deal with this is by applying radical innovation strategy. However, radical innovation strategy is far more less percentage in the success comparing with incremental innovation. Implication to organizational context is that the firm needs favor condition to its surrounding context by means of creating structure and process enabling innovation to thrive (Tidd et al., 2005). Considering condition of relationship under loosely, temporal, and dynamic and referring to structural archetype from Mintzberg as Tidd et. al. referred to, it seems that the socalled archetype structure of 'machine adhocracy' is appropriate. This type of structure actively encourages creativity and flexibility, emphasizing on team working, and participation in problem-solving.

Based on our results, we suggest that (1) huge and compelling research areas in field marketing strategy are open to examine, especially in issues of boundary work or process taking place within crossing the boundary, and boundary object or the focus that the firm considers within crossing the boundaries. As we realized that the literatures we have selected for this work cannot depict the clear picture yet, we hope (2) that more variety in term of discipline (for example, the socio-political, techno-economic, and spatial-temporal factor, or the combination among these factors is significant, especially in term of defining the condition of relationship and actors that is truly very context-based. 


\section{Reference}

Bach, Laurent, \& Matt, Mireille. (2005). From Economic Foundations to S\&T Policy Tools: a Comparative Analysis of the Dominant Paradigms. In P. Llrena \& M. Matt (Eds.), Innovation Policy in a Knowledge-Based Economy. Heidelberg: Springer.

Cepeda-Carrion, Ignacio, MarteloLandroguez, Silvia, Leal-Rodríguez, Antonio L., \& Leal-Millán, Antonio. (2016). Critical processes of knowledge management: An approach towardthe creation of customer value. European Research on Management and Business Economics, 23(1), 1-7. doi: http://dx.doi.org/10.1016/j.iedeen.201 6.03.001

Cohendet, Patrick, \& Mehyer-Krahmer, Frieder. (2005). Technology Policy in the Knowledge-Based Economy. In P. Llrena \& M. Matt (Eds.), Innovation Policy in a Knowledge-Based Economy. Heidelberg: Springer.

Dickinson, Harley D. (2013). Crossing Boundaries: Creating, Transferring and Using Knowledge. In J. Dzisah \& H. Etzkowitz (Eds.), The Age of Knowledge: the Dynamics of Universities, Knowledge, and Society (pp. 145-165). Chicago, IL: Haymarket Books.

Dodgson, Mark, Gann, David, \& Salter, Ammon. (2008). The Management of Technological Innovation (2nd ed.). New York: Oxford University Press.

Dzisah, James, \& Etzkowitz, Henry. (2013a). The Dynamics of Universities, Knowledge and Society. In J. Dzisah \& H. Etzkowitz (Eds.), The Age of Knowledge: the Dynamics of Universities, Knowledge and Society (pp. 1-7). Chicago, IL: Haymarket Books.

Dzisah, James, \& Etzkowitz, Henry. (2013b). The Triple Helix of Knowledge. In J. Dzisah \& $\mathrm{H}$. Etzkowitz (Eds.), The Age of Knowledge: the Dynamics of Universities, Knowledge, and Society (pp. 127-144). Chicago, IL: Haymarket Books.

Dzisah, James, \& Etzkowitz, Henry (Eds.). (2013c). The Age of Knowledgde: the Dynamics of Universities, Knowledge, and Society. Chicago, IL: Haymarket Books.

Edquist, Charles (Ed.). (1997). Systems of Innovation: Technologies, Institutions and Organizations. New York: Routledge.

Etzkowitz, Henry. (2013). Normative Change in Science and the Birth of the Triple Helix. In J. Dzisah \& $\mathrm{H}$. Etzkowitz (Eds.), The Age of Knowledge: the Dynamics of Universities, Knowledge and Society (pp. 11-34). Chicago, IL: Haymarket Books.

Fischer, Manfred M., \& Fröhlich, Josef (Eds.). (2001). Knowledge, Complexity and Innovation Systems. Heidelberg: Springer.

Hult, G. Tomas M., \& Jr., David J. Ketchen. (2017). Disruptive marketing strategy. AMS Review, 7(1-2), 20-25. doi: 10.1007/s13162-017-0097-4

Keszey, Tamara, \& Biemans, Wim. (2016). Sales-marketing encroachment effects on innovation. Journal of Business Research, 69(9), 3698-3706. doi: https://doi.org/10.1016/j.jbusres.2016 .03 .032

King, William R. (Ed.). (2009). Knowledge Management and Organizational Learning. New York: Springer.

Kotler, Philip, \& Amstrong, Gary. (2012). Principle of Marketing (14th ed.). New Jersey: Prentice Hall.

Kotler, Philip, \& Keller, Kevin Lane. (2007). Manajemen Pemasaran (12 ed. Vol. 2). Indonesia: PT. Indek.

Llrena, Patrick, \& Matt, Mireille (Eds.). (2005). Innovation Policy in a Knowledge-Based Economy: Theory and Practice. Heidelberg: Springer.

Llrena, Patrick, \& Schenk, Eric. (2005). Technology Policy and A-Synchronic Technologies: The Case of German High-Speed Trains. In P. Llrena \& M. 
Matt (Eds.), Innovation Policy in a Knowledge-Based Economy. Heidelberg: Springer.

Metcalfe, Amy Scott. (2013). Facilitating Knowledge Transfer: the Role of Intermediating Organization. In $\mathrm{J}$. Dzisah \& H. Etzkowitz (Eds.), The Age of Knowledge: the Dynamics of Universities, Knowledge, and Society (pp. 243-266). Chicago, IL: Haymarket Books.

Metcalfe, James Stanley. (2013). System Failure and the Case for Innovation Policy. In J. Dzisah \& H. Etzkowitz (Eds.), The Age of Knowledge: the Dynamics of Universities, Knowledge, and Society (pp. 47-74). Chicago, IL: Haymarket Books.

Miles, Jeffrey A. (2012). Management and Organization Theory (First ed.). San Francisco: Jossey-Bass.

Orlandi, Ludovico Bullini. (2016). Organizational capabilities in the digital era: Reframing strategic orientation. Journal of Innovation \& Knowledge, 1(3), 156-161. doi: http://dx.doi.org/10.1016/j.jik.2016.0 1.002

Perez, Carlota. (2005). Technological Revolutions and Financial Capital: the Dynamics of Bubbles and Golden Ages. Cheltenham, UK: Edward Elgar Publishing Limited.

Philips, Peter W. B. (2013). Governing Innovation in a Knowledge Society. In J. Dzisah \& H. Etzkowitz (Eds.), The Age of Knowledge: the Dynamics of Universities, Knowledge and Society (pp. 167-191). Chicago, IL: Haymarket Books.

Schwab, Klaus. (2016). The Fourth Industrial Revolution: what it means, how to respond. Retrieved 10 July, 2017, from http://www.weforum.org/agenda/201 6/01/the-fourth-industrial-revolutionwhat-it-means-and-how-to-respond

Senge, Peter M. (1990). The Fifth Discipline: The Art and Practice of Learning Organization. New York: Doubleday.
Tidd, Joe, Bessant, John, \& Pavitt, Keith (Eds.). (2005). Managing Innovation: Integrating Technological, Market and Organizational Change (Third ed.). West Sussex, England: John Wiley \& Sons Ltd.

Williams, Paul. (2010). Special Agents: The Nature and Role of Boundary Spanners. Paper presented at the Collaborative Futures: New Insights from Intra

and Inter-Sectoral Collaborations, Birmingham. Paper retrieved from http://www.download.bham.ac.uk/go vsoc/pdfs/special-agents-paper.pdf 